\title{
PERANCANGAN DAN PEMBUATAN WEBSITE UJIAN ONLINE BERBASIS WEB RESPONSIVE PADA MATAPELAJARAN SIMULASI DANKOMUNIKASI DIGITAL ( STUDI KASUS KELAS X SMK NEGERI 7 PADANG )
}

\author{
Menrisal $^{1}$, Indra Wiaya ${ }^{2}$, Imam Pradaya Putra ${ }^{3}$ \\ Fakultas Keguruan dan Ilmu Pendidikan, Universitas Putra Indonesia YPTK Padang \\ Email:menrisal@upiyptk.ac.id,indrawijaya25@gmail.com,imampradaya11@gmail.com
}

\begin{abstract}
Abstrak:
Penelitian ini dilatar belakangi oleh permasalahan keterbatasan sumber belajar yang ada di SMKN 7 Padang.Penelitian dan pengembangan ini bertujuan untuk mengetahui Validitas, Praktikalitas dan Efektifitas Website Ujian Online Berbasis Web Responsive di SMK Negeri 7 Padang .Penelitian ini menggunakan metode penelitian dan pengembangan $((R \& D)$. Metode penelitian ini menggunakan analisis (ADDIEModel), dengan desain dan langkah-langkah pengembangannya adalah sebagai berikut Analysis(analisis), Design (perancangan), Develop (pengembangan), Implementation (implementasi) dan Evaluation(evaluasi). Hasil uji validitas oleh para ahli Secara keseluruhan penilaian uji validator terhadap Website Ujian Online81,39\%, sehingga tingkat validitas dapat di interpretasikan valid digunakan. Hasil penilaian uji praktikalitas secara keseluruhan penilaian praktikalitas terhadap website ujian onlinesebesar 94,75\%, sehingga tingkat praktikalitas nya dapat di interpretasikan sangat praktis digunakan. Hasil penilaian uji efektivitas Secara keseluruhan penilaian efektivitas website ujian online sebesar 89,58\%, sehingga tingkat efektivitasnya dapat di interpretasikan sangat efektif digunakan. Berdasarkan penilaian beserta masukan ahli serta hasil dari uji coba lapangan website ujian online sudah teruji kelayakan, keunggulan, dan dapat digunakan pada proses pelaksanaan ujian di SMK N 7 Padang.
\end{abstract}

Kata kunci :Ujian Online, Web Responsive, Website 


\begin{abstract}
:
This research is based on the problem of limited learning resources in SMKN 7 Padang. This research and development aims to know the Validity, Practicality and Effectiveness of Web Responsive Online Exam Website in SMK Negeri 7 Padang. This research uses research and development methods ((REd). This research method uses analysis (ADDIEModel), with the design and development steps are as follows Analysis, Design, Develop, Implementation and Evaluation. Validity test results by experts Overall the validator test assessment on the Online Exam Website $81.39 \%$, so that the validity level can be interpreted as valid to use. The overall practicality test assessment of the practicality assessment of online exam websites was $94.75 \%$, so the practicality level can be interpreted very practically. The overall effectiveness assessment of the effectiveness assessment of online test websites is $89.58 \%$, so the effectiveness level can be interpreted very effectively used. Based on assessment along with expert input as well as results from field trials online test website has been tested feasibility, excellence, and can be used in the exam implementation process in SMK N 7 Padang.
\end{abstract}

Key Word : Online Exam, Web Responsive, Website

\title{
A. PENDAHULUAN
}

Kualitas pendidikan merupakan sebuah kebutuhan yang harus diutamakan, terutama bagi generasi penerus bangsa, sehingga pendidikan perlu mendapatkan dukungan dari seluruh lapisan masyarakat mulai dari orangtua siswa, lembaga pendidikan, hingga pemerintah. Dukungan tersebut dapat berupa berbagai macam hal, seperti penyediaan fasilitas-fasilitas yang mendukung proses belajar mengajar. Ujian sekolah adalah kegiatan yang dilakukan oleh satuan pendidikan untuk mengukur pencapaian kompetansi peserta didik sebagai pengukuran prestasi belajar atau pencapaian kompetensi sekolah.

Pada evaluasi konvensional tidak memberikan hasil evaluasi secara real time. Siswa dan orangtua harus menunggu berhari-hari untuk mengetahui hasil evaluasi, apakah anaknya lulus / tidak dalam mengikuti ujian kompetensi di sekolah.Teknologi komunikasi dan elektronik sudah berkembang sedemikian pesat, sehingga menyebabkan bidang pendidikan turut mengalami peningkatan dalam hal kualitas, kecepatan,kepraktisan dan juga kemudahan. Ujian konvensional pun bergeser ke arah digital, salah satunya dengan adanya ujian online.

Sistem ujian online merupakan bagian dari sistem informasi pendidikan jarak jauh dan dekat melalui media teknologi elektronik internet atau e-learning. Media teknologi informasi sangat erat kaitannya dengan sistem basis data sebagai media masukan dan penyimpanan data yang sesuai dengan kebutuhan para penggunanya. Sebagai aplikasi teknologi informasi, sistem ujian online berbasis web merupakan perangkat lunak yang menerapkan database management system (DBMS) dalam menangani perintah-perintah dan permintaan pengguna sistem terhadap basis data. Basis data system ujian online dibuat berdasarkan pada tahapan analisis sistem sampai dengan normalisasi basis data. Informasi data ujian online diperoleh dari proses pelaksanaan ujian secara konvensional.

Paris Langkis

Vol.1 Nomor 2, Maret 2021 
Berdasarkan uraian diatas, maka penulis tertarik membuat tugas akhir dengan judul"Perancangan dan Pembuatan Sistem Ujian Online Berbasis Web Mobile Pada Siswa Kelas X di SMK Negeri 7 Padang Tahun Ajaran 2019/2020”.

\section{B. TINJAUAN LITERATUR}

1. Website

Menurut Tim EMS (2014:1), Website adalah apa yang anda lihat via browser, sedangkan yang disebut sebagai "web" sebenarnya adalah sebuah aplikasi web, karena melakukan action tertentu dan membantu anda melakukan kegiatan tertentu. Ketika anda membuka facebook, path, twitter, atau instagram, itu adalah contoh-contoh aplikasi web.

2. Ujian Online

Ujian berbasis komputer merupakan ujian yang memanfaatkan komputer untuk menggantikan kertas atau paper-pencil dalam pengadministrasian tes (Samsul, 2013). Senada dengan hal tersebut, Kementerian Pendidikan dan Kebudayaan Republik Indonesia menjelaskan bahwa Computer Based Test (CBT) adalah sistem pelaksanaan ujian dengan menggunakan komputer sebagai media ujiannya (Kemdikbud, 2016).

3. Web Responsive

Menurut Slamet Riyanto(2014:11), istilah Responsive Web Design (RWD) diciptakan oleh desainer dan pengembangan web Etha Marcotte. Dalam sebuah artikel pada tahun 2010 untuk blog teknologi berjudul "A List Part" Marcotte menjelaskan teknik untuk perpanjangan peningkatan bagi mobile dalam cara efisien dan praktis, artinya pertanyaan media dan CSS bersyarat dapat digunakan untuk membuat tata letak yang fleksibel dan fluid untuk layar apapun.

4. Sistem Ujian Online Berbasis Web

2.4.1 User Interface (tampilan software)

2.4.2 Sistem soal ujian online

2.4.3 Sistem tampilan skoring soal ujian online

2.4.4 Sistem pelaporan hasil ujian online

5. Mata Pelajaran Simulasi dan Komunikasi Digital

Simulasi Digital adalah salah satu mata pelajaran pada Sekolah Menengah Kejuruan (SMK), sesuai pada Surat Keputusan Direktorat Jendral Pendidikan Dasar dan Menengah (Dirjen Dikdasmen) Nomor 130/D/KEP/KR/2017 tentang Struktur Kurikulum Pendidikan Menengah Kejuruan. Mata pelajaran Simdig dipelajari oleh siswa kelas X semua Bidang Keahlian SMK (C1). Pada dasarnya, mata pelajaran Simulasi Digital di Sekolah Menengah Kejuruan merupakan mata bertujuan membekali siswanya dengan keterampilan kejuruan untuk mengatasi masalah. Dengan demikian, sejak awal siswa SMK harus mendudukkan dirinya sebagai bagian dari solusi, bukan bagian dari masalah.

\section{METODOLOGI}

1. Jenis Penelitian 
Penelitian ini menggunakan penelitian dan pengembangan atau biasa disebut dengan RED (research and development),yaitu metode penelitian yang digunakan untuk menghasilkan produk tertentu, dan menguji keefektifan produk tersebut.

Model pengembangan dalam penelitian ini menggunakan model Analysis-DesignDevelopment-Implementation-Evaluation (ADDIE).

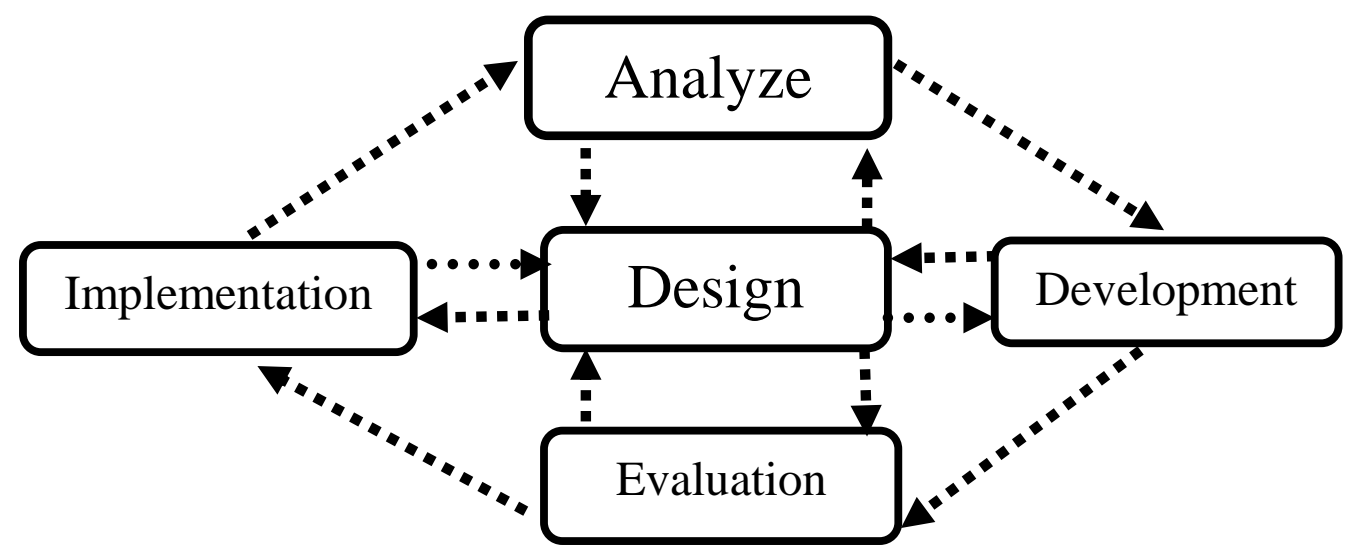

Gambar 1. Model Pengembangan ADDIE

2. Subjek Penelitian

Subjek dalam penelitian ini diambil dari siswa kelas X mata pelajaran Simulasi Digital Semua Jurusan di SMK Negeri 7 Padang tahun ajaran 2019/2020 berjumlah 36 siswa.

3. Jenis Data

Jenis data yang diambil dalam penelitian ini adalah data primer. Data pertama berupa hasil validasi media pembelajaran berbasis Android yang diberikan oleh validator. Data kedua diperoleh dari pelaksanaan uji coba media pembelajaran berbasis Android.

4. Instrumen Penelitian

1. Instrumen Kevalidan

Instrumen kevalidan digunakan untuk mengetahui apakah media pembelajaran berbasis Android yang telah dirancang valid atau tidak.

Tabel 1. Kisi Kisi Angket Validator

\begin{tabular}{cllc}
\hline No & \multicolumn{1}{c}{ Indikator } & \multicolumn{1}{c}{ Item } & Jumlah \\
\hline 1 & Kelayakan Isi. & $1,2,3,4,5$ & 5 \\
\hline 2 & Komponen Kebahasaan & $6,7,8,9$ & 4 \\
\hline 3 & Komponen Penyajian & $10,11,12,13,14,15,16$ & 7 \\
\hline 4 & KomponenKegrafikan. & $17,18,19,20$ & 4 \\
\hline \multicolumn{2}{c}{ Total Item } \\
\hline \multicolumn{2}{c}{ Sumber :Hastuti, dkk (2015:115) }
\end{tabular}

Untuk mengubah data kualitatif ke bentuk kuantitatif, maka angket selain di beri alternatif jawaban masing-masing mempunyai bobot dan skor dari setiap jawaban dari pernyataan dapat dilihat pada tabel berikut; 
Tabel 2. Penilaian Jawaban

\begin{tabular}{lcc}
\hline \multicolumn{1}{c}{ Pilihan } & Keterangan & Bobot \\
\hline Sangat Setuju & SS & 5 \\
\hline Setuju & S & 4 \\
\hline Kurang Setuju & KS & 3 \\
\hline Tidak Setuju & TS & 2 \\
\hline Sangat Tidak Setuju & STS & 1 \\
\hline \multicolumn{4}{c}{ Sumber : Sugiyono (2014 : 93) }
\end{tabular}

2. Intrumen Kepraktisan

Setelah instrument dinyatakan valid oleh validator, selanjutnya beberapa instrument tersebut digunakan untuk uji kepraktisan.

Tabel 3. Kisi-Kisi Angket Praktikalitas

\begin{tabular}{cllc}
\hline No & \multicolumn{1}{c}{ Indikator } & \multicolumn{1}{c}{ Item } & Jumlah \\
\hline 1 & Keadaan Penggunaan & $1,2,3,4,5,6,7,8$ & 8 \\
\hline 2 & Efektifitas Waktu Pembelajaran & $9,10,11,12,13$ & 5 \\
\hline 3 & Manfaat & $14,15,16,17,18,19,20$ & 7 \\
\hline \multicolumn{2}{r}{ Total Item } \\
\hline
\end{tabular}

Sumber : Riza E Handayani (2014: 125)

Instrumen yang digunakan disusun menurut pola skala dalam bentuk kontiniu yang terdiri dari lima kategori dan pernyataan angket bersifat positif.

Tabel 4. Penilaian Jawaban

\begin{tabular}{lcc}
\multicolumn{1}{c}{ Pilihan } & Keterangan & Bobot \\
\hline Sangat Setuju & SS & 5 \\
\hline Setuju & S & 4 \\
\hline Kurang Setuju & KS & 3 \\
\hline Tidak Setuju & TS & 2 \\
\hline Sangat Tidak Setuju & STS & 1 \\
\hline
\end{tabular}

Sumber : Sugivono (2014 : 93)

3. Instrumen Keefektifan

Cara pengujian keefektifan media pembelajaran berbasis Android digunakan soal tes belajar.Untuk mengetahui kemampuan belajar siswa, siswa menjawab soal tes belajar.Soal tes belajar diberikan setelah siswa mengikuti proses pembelajaran dengan media pembelajaran berbasis Android.

\subsection{Teknik Analisa Data}

1. Analisis Uji Validitas media pembelajaran berbasis Android

a) Memberikan skor jawaban dengan kriteria berdasarkan skala Likert yang dimodifikasi oleh Sugiyono (2014 : 93) yaitu :

Tabel 6. Penilaian Jawaban validitas

Pilihan Keterangan Bobot




\begin{tabular}{lcc}
\hline Sangat Setuju & SS & 5 \\
\hline Setuju & S & 4 \\
\hline Kurang Setuju & KS & 3 \\
\hline Tidak Setuju & TS & 2 \\
\hline Sangat Tidak Setuju & STS & 1 \\
\hline \multicolumn{2}{c}{ Sumber : Sugiyono $(2014: 135)$}
\end{tabular}

b) Menentukan skor tertinggi

Skor tertinggi $=$ jumlah validator $\mathrm{x}$ jumlah item pertanyaan $\mathrm{x}$ skor maksimum.

c) Menentukan jumlah skor dari masing-masing validator dengan menjumlahkan semua skor yang di peroleh dari masing-masing indikator.

d) Menentukan skor yang diperoleh dengan menjumlahkan skor dari masing-masing validator.

e) Penentuan nilai validitas dimodifikasi dari Purwanto (2010:102) sebagai berikut: $N P=\frac{R}{S M} \times 100$.

Keterangan :

$\mathrm{NP} \quad=$ Nilai persen yang dicari atau yang diharapkan

$\mathrm{R}=$ = Skor mentah yang diperoleh siswa

SM = Skor Maksimum ideal dari tes yang bersangkutan

$100=$ Bilangan Tetap

f) Memberikan penilaian validitas dengan kriteria yang dimodifikasi dari Purwanto (2010 : 82) berikut ini :

Tabel 7. Klasifikasi Aspek Penilaian Validitas

\begin{tabular}{ccc}
\hline No & Nilai & Aspek yang Dinilai \\
\hline 1 & $90 \%-100 \%$ & Sangat Valid \\
\hline 2 & $80 \%-89 \%$ & Valid \\
\hline 3 & $65 \%-79 \%$ & Cukup Valid \\
\hline 4 & $55 \%-64 \%$ & Kurang Valid \\
\hline 5 & $\leq 54 \%$ & Tidak Valid \\
\hline & \multicolumn{2}{c}{ Sumber : Purwanto $(2010: 82)$}
\end{tabular}

g) Kemudian menentukan nilai distribusi frekuensi validitas yang dimodifikasi dari Prof. Dr. H. Agus I. Irianto berikut ini:

$\mathrm{R}=$ data tertinggi - data terendah

$\mathrm{K}=1+3.3 \log \mathrm{n}$

$\mathrm{P}=\frac{\mathrm{R}}{\mathrm{K}}$

Keterangan :

$\mathrm{P}=$ Panjang kelas interval

$\mathrm{R}=$ Hitung jarak atau rentangan

$\mathrm{K}=$ Jumlah kelas

2. Analisis Uji Praktikalitas media pembelajaran berbasis Android

Data uji praktikalitas penggunaan media pembelajaran berbasis Android dianalisis dengan menggunakan rumus yang dimodifikasi dari Purwanto (2010: 102) berikut ini:

$\mathrm{NP}=\frac{\mathrm{R}}{\mathrm{SM}} \times 100$. 
Keterangan :

$\mathrm{NP}=$ Nilai persen yang dicari atau yang diharapkan

$\mathrm{R}=$ = Skor mentah yang diperoleh siswa

$\mathrm{SM}=$ Skor Maksimum ideal dari tes yang bersangkutan

$100=$ Bilangan Tetap

Setelah presentase diperoleh, dilakukan pengelompokkan sesuai kriteria yang dimodifikasi dari Purwanto (2010 : 103) berikut ini :

Tabel 8. Penilaian Praktikalitas

\begin{tabular}{lcc}
\hline No & Nilai & Aspek Yang Dinilai \\
\hline 1 & $86 \%-100 \%$ & Sangat Praktis \\
\hline 2 & $76 \%-85 \%$ & Praktis \\
\hline 3 & $60 \%-75 \%$ & Cukup Praktis \\
\hline 4 & $55 \%-59 \%$ & Kurang Praktis \\
\hline 5 & $\leq 54 \%$ & Tidak Praktis \\
\hline \multicolumn{3}{c}{ Sumber : Purwanto (2010: 103$)$}
\end{tabular}

Kemudian menentukan nilai distribusi frekuensi praktikalitas yang dimodifikasi dari Prof. Dr. H. Agus I. Irianto berikut ini:

$\mathrm{R}=$ data tertinggi - data terendah

$\mathrm{K}=1+3.3 \log \mathrm{n}$

$\mathrm{P}=\frac{\mathrm{R}}{\mathrm{K}}$

Keterangan :

$\mathrm{P} \quad=$ Panjang kelas interval

$\mathrm{R} \quad=$ Hitung jarak atau rentangan

$\mathrm{K} \quad=$ Jumlah kelas

3. Analisis Efektifitas Media pembelajaran berbasis Android

Data angket efektifitas Media pembelajaran berbasis Android diperoleh dengan cara menghitung skor siswa yang menjawab masing-masing item sebagaimana terdapat pada angket. Data tersebut dianalisis dengan teknik persentase yang dinyatakan oleh Purwanto (2010 : 102) sebagai berikut :

$\mathrm{NP}=\frac{\mathrm{R}}{\mathrm{SM}} \times 100$.

Keterangan :

$\mathrm{NP} \quad=$ Nilai persen yang dicari atau yang diharapkan

$\mathrm{R}=$ = Skor mentah yang diperoleh siswa

$\mathrm{SM}=$ Skor Maksimum ideal dari tes yang bersangkutan

$100=$ Bilangan Tetap

Hasil yang diperoleh di interprestasikan dengan menggunakan kriteria sebagai berikut :

Tabel 9. Penilaian Efektivitas

\begin{tabular}{llc}
\hline No & Nilai & Aspek Yang Dinilai \\
\hline 1 & $86 \%-100 \%$ & Sangat Baik \\
\hline 2 & $76 \%-85 \%$ & Baik \\
\hline 3 & $60 \%-75 \%$ & Cukup \\
\hline 4 & $55 \%-59 \%$ & Kurang \\
\hline
\end{tabular}




\begin{tabular}{lcc}
\hline $5 \leq 54 \%$ & Kurang Baik \\
\hline & Sumber : Purwanto $(2010: 103)$
\end{tabular}

Kemudian menentukan nilai distribusi frekuensi efektifitas yang dimodifikasi dari Prof. Dr. H. Agus I. Irianto berikut ini:

$\mathrm{R}=$ data tertinggi - data terendah

$\mathrm{K}=1+3.3 \log \mathrm{n}$

$\mathrm{P}=\frac{\mathrm{R}}{\mathrm{K}}$

Keterangan :

$\mathrm{P} \quad=$ Panjang kelas interval

$\mathrm{R} \quad=$ Hitung jarak atau rentangan

$\mathrm{K}=$ Jumlah kelas

\subsection{Rancangan Interface}

Desain user interface merupakan desain tampilan sistem yang akan dibuat, mulai dari desain input dan desain ouput.

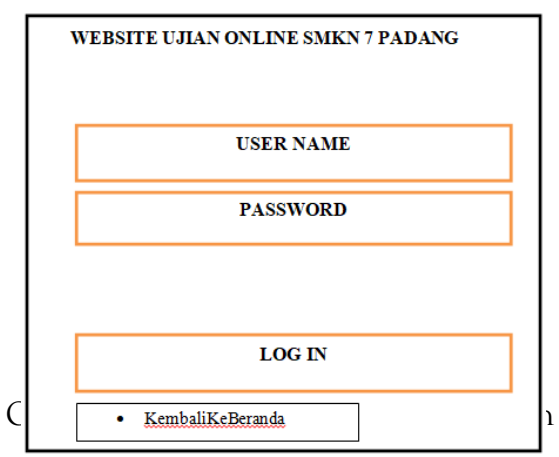

\section{HASIL DAN PEMBAHASAN}

1. Hasil Rancangan Tampilan

1. Halaman Login

\section{Paris Langkis}

Vol.1 Nomor 2, Maret 2021 


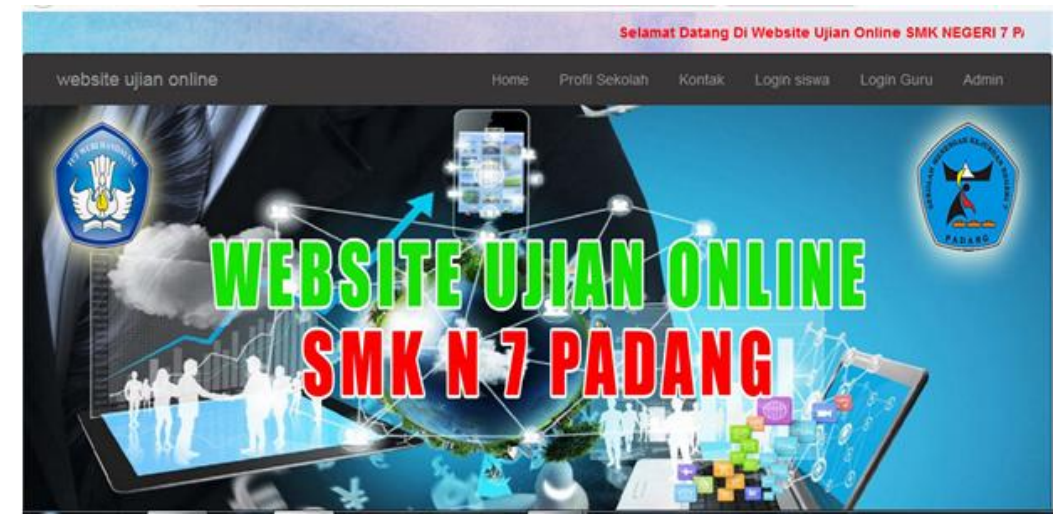

Gambar 3. Halaman Login

\section{Analisa DataUji Validasi}

Uji validitas dilakukan oleh 3 orang validator ahli media. penilaian dari validator untuk website ujian onlineberbasis webdi tinjau dari aspek (1) Kelayakan isi: 78,67\%; (2) Komponen Kebahasaan: 81,67\%; (3) Komponen Penyajian: 81,90\%; (4) Komponen Kegrafikan: 83,33\%. Secara keseluruhan penilaian uji validator terhadap website ujian online sebesar $81,39 \%$, sehingga website ujian onlinetersebut bisa dikatakanvalid digunakan untuk pelaksanaan ujian.

Tabel 10. Distribusi Frekuensi Skor Angket Validitas

\begin{tabular}{cccc}
\hline No & Kelas - Interval & Fo & $\% F_{0}$ \\
\hline 1 & 79 & 1 & 33.33 \\
\hline 2 & 80 & 0 & 0.00 \\
\hline 3 & 81 & 0 & 0.00 \\
\hline 4 & 82 & 1 & 33.33 \\
\hline 5 & 83 & 1 & 33.33 \\
\hline & Jumlah & 3 & 100 \\
\hline
\end{tabular}

Sumber: Pengolahan data mandiri

Berdasarkan pada tabel diatas dapat dijelaskan untuk mencari perhitungan interval kelas dan panjang kelas.

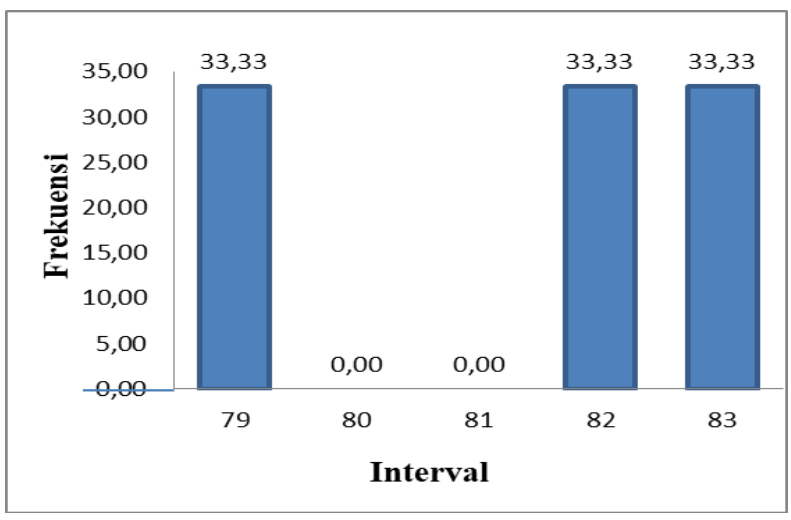

Gambar3.Histogram Angket Validitas

\section{Paris Langkis}

Vol.1 Nomor 2, Maret 2021 
3. Uji Praktikalitas

Uji coba praktikalitas yang dilakukandari 36 orang siswa untuk website ujian online yang ditinjau dari aspek (1) Keadaan Penggunaan :96,32\%; (2) Efektifitas Waktu Pelaksanaan : 94,24\%; (3) Manfaat : 93,70\%. Secara keseluruhan penilaian uji praktikalitas terhadap website ujian onlinesebesar $94,75 \%$, sehingga website tersebut bisa dikatakan sangat praktis digunakan siswa untuk pelaksanaan ujian di SMK Negeri 7 Padang. sehingga media tersebut bisa dikatakan sangat praktis digunakan siswa untuk pembelajaran simulasi digital.

Tabel 11. Distribusi Frekuensi Skor Angket Praktikalitas

\begin{tabular}{cccc}
\hline No & Kelas - Interval & FO & \%FO \\
\hline 1 & $82-83$ & 1 & 2.78 \\
\hline 2 & $84-85$ & 2 & 5.56 \\
\hline 3 & $86-87$ & 1 & 2.78 \\
\hline 4 & $88-89$ & 13 & 36.11 \\
\hline 5 & $90-91$ & 9 & 25.00 \\
\hline 6 & $92-93$ & 7 & 19.44 \\
\hline 7 & $94-95$ & 3 & 8.33 \\
\hline \multicolumn{5}{c}{ Sumber: Pengolahan Data Mandiri } \\
\hline \multicolumn{3}{c}{ Jumlah } & 100.00
\end{tabular}

Berdasarkan pada tabel tersebut dapat dijelaskan untuk mencari perhitungan interval kelas dan panjang kelas.

\section{Angket Praktikalitas}

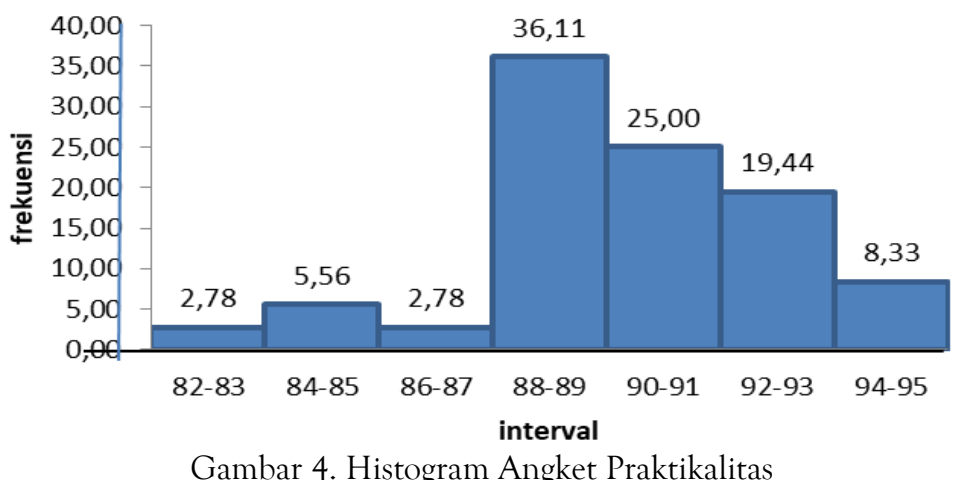

4. Uji Efektivitas

Uji efektivitas penilaian dari 36 siswa untuk website ujian online yang ditinjau dari setiap butir soal dengan rata-rata nilai soal keseluruhan adalah $89,58 \%$, sehingga website ujian online tersebut bisa dikatakan Sangat Efektif. Untuk memperoleh gambaran yang jelas tentang distribusi skor angket Efektifitas dapat dilihat pada tabel berikut :

Tabel 12. Distribusi Frekuensi Skor Angket Efektifitas

\begin{tabular}{cccc}
\hline No & Kelas - Interval & Fo $_{0}$ & $\%_{F_{0}}$ \\
\hline 1 & $70-73$ & 1 & 2.78 \\
\hline
\end{tabular}




\begin{tabular}{|c|c|c|c|}
\hline 2 & $74-77$ & 2 & 5.56 \\
\hline 3 & $78-81$ & 4 & 11.11 \\
\hline 4 & $82-85$ & 4 & 11.11 \\
\hline 5 & $86-89$ & 0 & 0.00 \\
\hline 6 & $90-93$ & 6 & 16.67 \\
\hline \multirow[t]{2}{*}{7} & $94-97$ & 19 & 52.78 \\
\hline & Jumlah & 36 & 100 \\
\hline
\end{tabular}

Berdasarkan pada tabel diatas dapat dijelaskan untuk mencari perhitungan interval kelas dan panjang kelas.

\section{Angket Efektifitas}

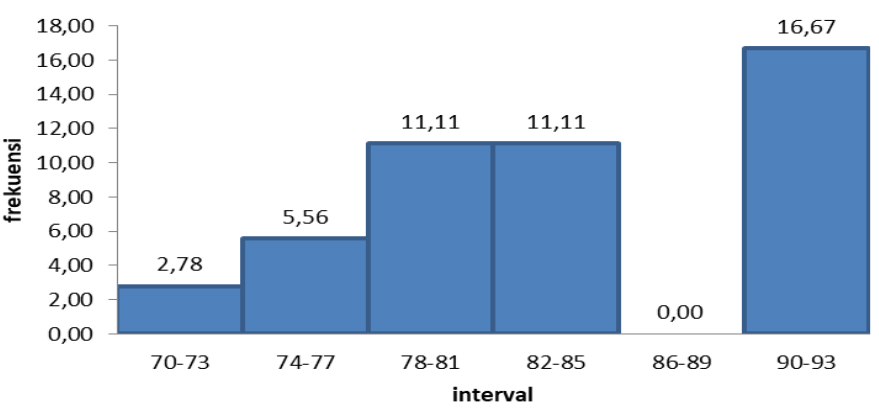

Gambar 5. Histogram Soal TesEfektifitas

\subsection{Pembahasan}

Berdasarkan pernyataan tersebut dapat disimpulkan bahwa website ujian online di SMK Negeri 7 Padang Tahun Ajaran 2019/2020 layak digunakan dalam pelaksanaan ujiankarena telah di uji kevalidannya dan di uji coba terhadap siswa mengenai praktikalitas dan efektifitas.

Tabel 13. Hasil uji coba Aplikasi Android

\begin{tabular}{llc}
\multicolumn{1}{c}{ Hasil Uji Coba } & Presentase & Keterangan \\
\hline Validasi & $81,39 \%$ & Valid \\
\hline Praktikalitas & $94,75 \%$ & Sangat Praktis \\
\hline Efektifitas & $89,58 \%$ & Sangat Baik \\
\hline
\end{tabular}

\section{E. KESIMPULAN}

1. Kesimpulan

Perancangan dan pembuatan website ujian onlinemengikuti prosedur dan pengembangan (Research and Development) Sugiyono (2014:298). Berdasarkan diskripsi, analisis data, dan pengembangan website ujian online dapat disimpulkan sebagai berikut :

1. Validitas melalui penilaian uji validator terhadap website ujian online sebesar $81,39 \%$, sehingga tingkat validitas dapat di interprestasikan valid digunakan.

2. Praktikalitas website ujian online adalah sebesar $94,75 \%$, sehingga tingkat praktikalitasnya dapat di interprestasikan sangat praktis digunakan.

3. Efektifitas website ujian online adalah sebesar $89,58 \%$, sehingga tingkat efektifitas nya dapat di interprestasikan baik digunakan.

\section{Paris Langkis}

Vol.1 Nomor 2, Maret 2021 


\section{REFERENSI}

Andri Hendriadi \& Nono Heryana. (2014). Pengembangan Sistem Operasi Berbasis Open Source Dalam Pemilihan Paket Distribusi Untuk Menunjang Kegiatan Akademik Dilingkungan Unsika. Jurnallmiah Sulusi. Vol 1 (No 2), 1-9. http://journal.unsika.ac.id/index.php/solusi/issue/archive

Arief Hidayat, Victor Gayuh Utomo dan Henry Anggoro Djohan.2016. "Penerapan Responsve Web Design Dalam Perancangan Sistem Modul Online Adaptif". Journal of Information System, Volume 12, Issue 1.

Astria Firman, Hans F. Wowor, Xaverius Najoan.” Sistem Informasi Perpustakaan Online Berbasis Web”. E-journal Teknik Elektro dan Komputer vol.5 no.2.

Budi Prasetyo, Timothy John Pattiasina, Anggya Nanda Soetarmono. 2015.”Perancangan dan Pembuatan Sistem Informasi Gudang" TEKNIKA Volume.4 Nomor 1.

EMS Tim.2014.Teori dan Praktik PHP-MySQL Untuk Pemula. Jakarta: PT Elex Media Kumputindo.

Fahmy, S., Haslinda, N., Roslina, W., \& Fariha, Z. (2012).Evaluating the Quality of Software in e-Book Using. International Journal of Control and Automation

Febrianto, 2016. Pengembangan Sistem Ujian Online Berbasis Web Pada Mata Pelajaran Teknik Listrik di Sekolah Menengah Kejuruan Yogyakarta

H Rafiza.2016. Panduan dan Referensi Kamus Fungsi PHP5 untuk Membangun Database Berbasis Web.Jakarta:PT Elex Media Komputindo.

Imansyah, Muhammad. 2003. PHP dan MySQL untuk Orang Awam. Palembang : CV. Maxikom.

Kendall \& Kendall. 2003. Analisis Perancangan Sistem Edisi Kelima. Jakarta: PT. Indeks.

MADCOMS. 2012.Adobe Dreamweaver CS6 dan PHP MySql Untuk Pemula. Yogyakarta: Andi OFFSET.

Menrisal, M., Yunus, Y., \& Rahmadini, N. S. (2019). Perancangan dan Pembuatan Modul Pembelajaran Elektronik Berbasis Project Based Learning Mata Pelajaran Simulasi Digital SMKN 8 Padang. JURNAL KOULUTUS, 2(1), 1-16.

Muhajir Affandi, 2018. Teknologi Informasi dan Komunikasi dalam Pendidikan. Penerbit YNHW

Muhammad Yaumi, 2018. Media dan Teknologi Pembelajaran. Prenada Media

Rozi A. Zaenal, 2016, Modern Web Design.Elex Media Komputindo

Sandi Febriyatna Ramadhan dan Uus Rusmawan, 2018, Membangun Aplikasi dengan PHP, Codeigniter dan Ajax.Elex Media Komputindo

Solichin Achmad, 2015, Pemrograman Web dengan PHP dan MySQL . Achmad Solichin Sutanta, Edhi. 2004. Sistem Informasi Manajemen. Bandung : Graha Ilmu.

Sutarman.2007. Membangun Aplikasi Web dengan PHP \& MySQL.Yogyakarta :Graha Ilmu.

Syachbana dan Akib Z., Perancangan Webiste Menggunakan Responsive Web Design., SIGMATA 26, 2014.

Wandah Wibawanto, 2017. Desain dan Pemrograman Multimedia Pembelajaran Interaktif. Cerdas Ulet Kreatif Publisher

Paris Langkis

Vol.1 Nomor 2, Maret 2021 
Y. Kustiyahningsih, D. Rosa, Pemrograman Basis Data Berbasis WEB Menggunakan PHP dan Mysql, Yogyakarta : Graha Ilmu, 2011. 